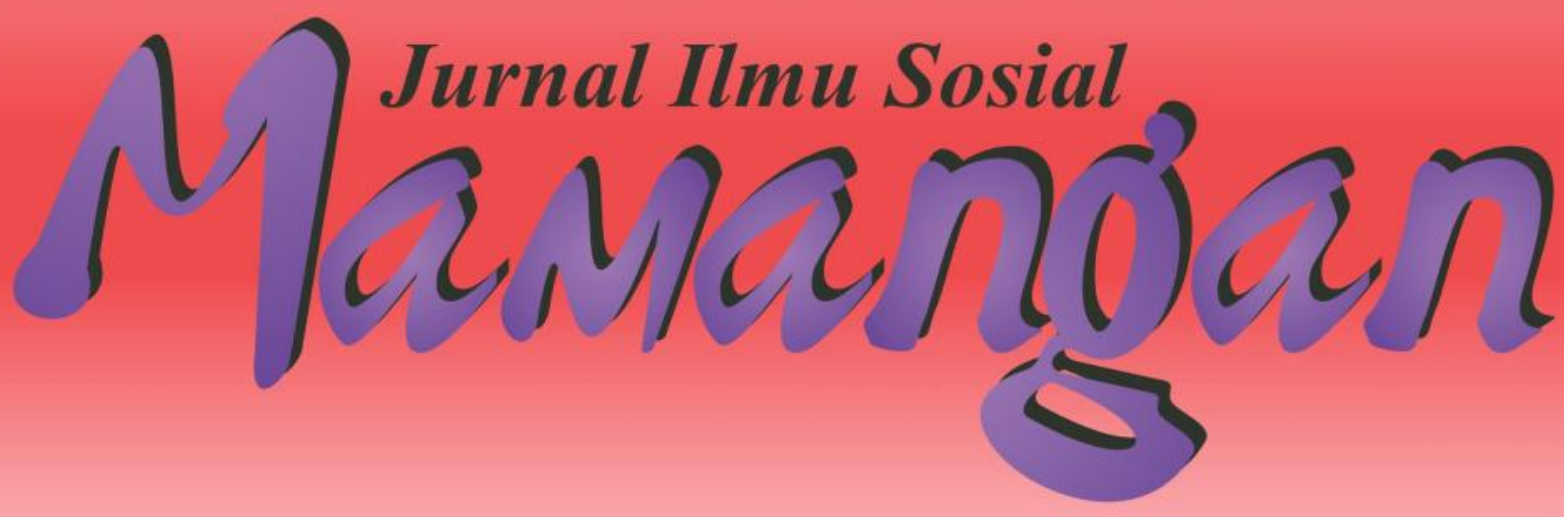

Diamika Perempuan Pedagang Makanan Di Sicincin

Elsa melia Roza, Yulkardi \& Rinel Fitlayeni

Motivasi \& Strategi Keluarga Miskin Nagari Talu, Kab. Pasaman Barat Melanjutkan Pendidikan Anak Ke Perguruan Tinggi

Cici Rahma Sari, Elvawati \& Dian Kurnia Anggreta

Dampak Sosial Ekonomi Objek Wisata The Unique Park Waterboom Di Kota Sawahlunto

Lisa Desatria, Fachrina \& Faishal Yasin

Pandangan Rumah Tangga Sasaran (RTS) Terhadap Pelaksanaan Dana Bergulir PNPM-MP Di Kelurahan Balai Gadang, Kota Padang Elparianti, ArdiAbbas \& Elvawati

Kehidupan Waria Di Jorong Mandiangin, Kecamatan Kinali, Kabupaten Pasaman Barat

Susanki \& Dian Anggraini Oktavia

Fungsi Koperasi Serba Usaha Ekonomi Desa (KSU-ED) Terhadap Masyarakat Nagari Tabek Talang Babungo, Kabupaten Solok Yenti Welia, Witrianto \& Refni Yulia 


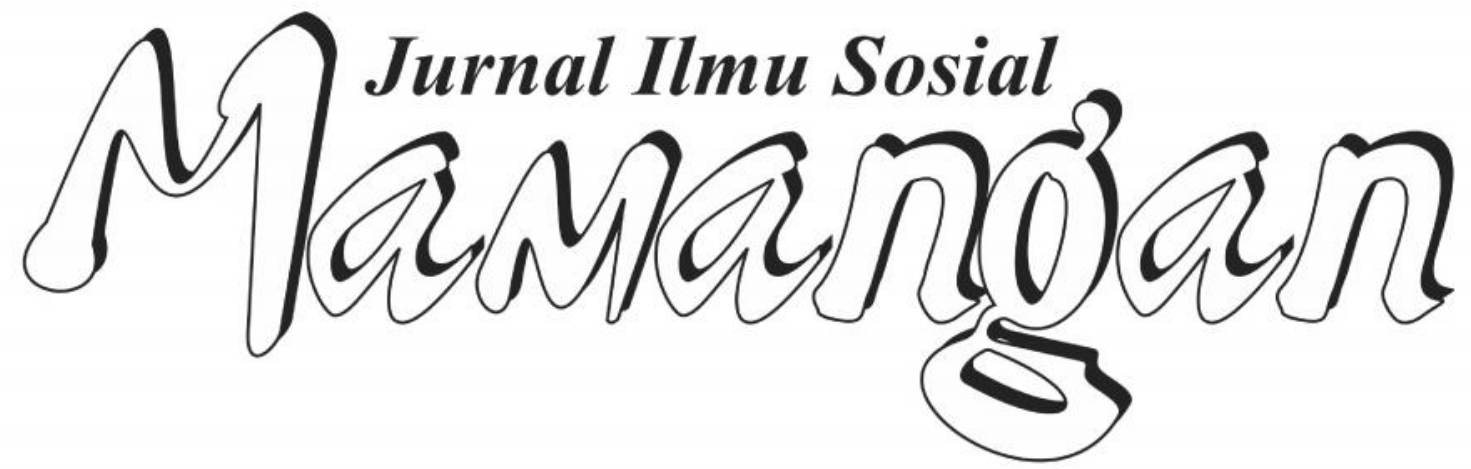




\section{Mitra Bestari}

Prof. Dr. Afrizal, MA. (FISIP, Unand Padang)

Dr. A. Latief Wiyata, M. Si. (Universitas Jember, Jember)

Prof. Dr. Badaruddin, M. Si. (FISIP, USU Medan)

Dr. Fikarwin Zuska, M. Si. (FISIP, USU Medan)

Nurus Shalihin, M. Si., Ph.D. (Fak. Ushuluddin IAIN Imam Bonjol Padang)

Dr. Semiarto A. Purwanto, M. Si. (FISIP, UI Jakarta)

Dr. Wahyu Wibowo, M. Si. (Universitas Nasional, Jakarta)

\section{Dewan Redaksi}

Dr. Zusmelia, M. Si.

Dr. Maihasni, M. Si.

Adiyalmon, S. Ag., M. Pd.

Firdaus, S. Sos., M. Si.

\section{Pemimpin Redaksi}

Firdaus, S. Sos., M. Si.

\section{Anggota Redaksi}

Dian Kurnia Anggreta, S. Sos., M. Si.

Rinel Fitlayeni, S. Sos., MA.

Surya Prahara, SH.

ISSN: 2301-8496

\section{Alamat Redaksi:}

Laboratorium Program Studi Pendidikan Sosiologi, STKIP PGRI Padang

Jl. Gunung Pangilun, Padang

Email: redaksimamangan@yahoo.com

Penerbit :

Program Studi Pendidikan Sosiologi, STKIP PGRI Padang

\section{Contac person :}

Firdaus (Hp. 085263881221/Email : daus gila@yahoo.com) 


\section{DAFTAR ISI}

Diamika Perempuan Pedagang Makanan Di Sicincin

Elsa melia Roza, Yulkardi \& Rinel Fitlayeni.

Motivasi \& Strategi Keluarga Miskin Nagari Talu, Kab. Pasaman Barat Melanjutkan Pendidikan Anak Ke Perguruan Tinggi

Cici Rahma Sari, Elvawati \& Dian Kurnia Anggreta.

Dampak Sosial Ekonomi Objek Wisata The Unique Park Waterboom Di Kota Sawahlunto

Lisa Desatria, Fachrina \& Faishal Yasin

Pandangan Rumah Tangga Sasaran (RTS) Terhadap Pelaksanaan Dana Bergulir PNPM-MP Di Kelurahan Balai Gadang, Kota Padang

Elparianti, Ardi Abbas, Elvawati

Kehidupan Waria Di Jorong Mandiangin, Kecamatan Kinali, Kabupaten Pasaman Barat

Susanki \& Dian Anggraini Oktavia

Fungsi Koperasi Serba Usaha Ekonomi Desa (KSU-ED) Terhadap Masyarakat Nagari Tabek Talang Babungo, Kabupaten Solok 


\title{
MOTIVASI DAN STRATEGI KELUARGA MISKIN NAGARI TALU, KAB. PASAMAN BARAT MELANJUTKAN PENDIDIKAN ANAK KE PERGURUAN TINGGI
}

\author{
Cici Rahma Sari, Elvawati \& Dian Kurnia Anggreta \\ Sekolah Tinggi Keguruan dan Ilmu Pendidikan (STKIP) PGRI Sumatera Barat
}

\begin{abstract}
Poverty described as a lack of income to fulfill the basic necessities of life. One way to reduce poverty is education. Education is not only a means of forming human resources with high competitiveness, but expected to also determine the occurrence of various social changes. Poverty makes it difficult for people to get a better education. It's caused by education cost is expensive in general, and not all parents are able to finance their child to studying. In Nagari Talu, $15 \%$ of poor parents send their children to college. This paper describes the motive and strategy of poor parents sent their children to college. This research was conducted with a qualitative approach and descriptive type. Informants were selected by proposive. Data collected through observation, interviews and study document. The result showing the parents motivation is to change the fate and environmental factors. The parents strategy is double living, assistance from extended family, borrowing and seek scholarships.
\end{abstract}

Keywords : Motivation, Strategy, Poor Family, College.

\begin{abstract}
ABSTRAK
Kemiskinan lazimnya digambarkan sebagai kekurangan pendapatan untuk memenuhi kebutuhan hidup yang pokok. Salah satu jalan untuk keluar dari kemiskinan adalah pendidikan. Pendidikan bukan saja sebuah alat pembentuk sumber daya manusia yang berdaya saing tinggi, melainkan diharapkan juga ikut menentukan terjadinya berbagai perubahan sosial. Namun kemiskinan membuat masyarakat sulit untuk mendapatkan pendidikan yang lebih baik. Hal ini dikarenakan biaya pendidikan pada umumnya mahal dan tidak semua orang tua mampu membiayai studi anaknya. Di Nagari Talu 15\% orang tua menyekolahkan anaknya ke pergurun tinggi dengan kondisi kehidupan mereka miskin. Tulisan ini mendeskripsikan strategi orang tua miskin melanjutkan pendidikan anaknya ke perguruan tinggi. Penelitian ini dilakukan dengan pendekatan kualitatif dan tipe deskriptif. Informan penelitian dipilih secara proposive. Dengan proses pengumpulan data melalui observasi, wawancara dan studi dokumen. Penelitian menunjukkan bahwa motivasi orang tua dalam melanjutkan studi anaknya ke perguruan tinggi adalah untuk untuk merubah nasib dan faktor lingkungan. Adapun strategi yang digunakan orang tua meanjutkan studi anaknya keperguruan tinggi adalah dengan pola nafkah ganda, bantuan dari keluarga luas, meminjam dan mengusahakan beasiswa.
\end{abstract}

Kata Kunci: Motivasi, Strategi, Keluarga Miskin, Pendidikan Tinggi

Jurnal Ilmu Sosial Mamangan, Volume II Nomor 2, juli-Desempber 2013 | 74 


\section{PENDAHULUAN}

Kemiskinan merupakan masalah sosial yang bersifat global. Artinya kemiskinan merupakan masalah yang dihadapi dan menjadi perhatian banyak orang di dunia. Kemiskinan pada hakikatnya menunjukkan pada situasi kesengsaraan dan ketidakberdayaan yang dialami seseorang baik akibat ketidakmampuan negara atau masyarakat memberikan perlindungan sosial kepada warganya (Suharto, 2009). Kemiskinan lazimnya digambarkan sebagai kekurangan pendapatan untuk memenuhi kebutuhan hidup yang pokok. Sekelompok anggota masyarakat dikatakan berada dibawah garis kemiskinan jika pendapatan kelompok anggota masyarakat ini tidak cukup untuk memenuhi kebutuhan hidup yang paling pokok seperti pangan, pakaian dan tempat tinggal (Setiadi \& Kolip, 2011)

Salah satu jalan untuk keluar dari kemiskinan adalah pendidikan. Pendidikan lebih diarahkan pada bagaimana menjadikan pendidikan sebagai barang dagangan yang menghasilkan keuntungan sebesar-besarnya (Amtu, 2011). Pendidikan menyiapkan sebuah generasi yang siap memasuki masyarakat yang berbasis pengetahuan. Pendidikan memiliki peran yang besar dalam menyediakan sumber daya manusia yang berkualitas dan daya saing tinggi (Maliki, 2010). Pendidikan bukan saja sebagai alat membentuk sumber daya manusia yang berdaya saing tinggi, melainkan juga ikut menentukan terjadinya berbagai perubahan sosial (Maliki, 2010). Seperti bidang teknologi, ilmu pengetahuan, maupun pola pikir masyarakat. Perubahan tersebut tidak hanya menyentuh perkotaan tapi juga pedesaan mulai mengalami perkembangan dn perubahan.

Namun kemiskinan membuat masyarakat sulit untuk mendapatkan pendidikan yang lebih baik. Hal ini dikarenakan biaya pendidikan pada umumnya mahal, tidak semua orang tua mampu membiayai studi anaknya. Meskipun adanya program penanggulangan kemiskinan yang dilakukan oleh pemerintah seperti: bantuan dan perlindungan sosial ditujukan untuk perlindungan dan pemenuhan hak atas pendidikan, kesehatan, pangan, sanitasi, air bersih dan diwujudkan dalam bentuk beras miskin (Raskin), jaminan kesehatan (Jamkesmas), BOS (Bantuan Operasional Sekolah), PHK (Program Keluarga Harapan) dan BLT (Bantuan Langsung Tunai). Tapi dengan bantuan tersebut belum bisa merubah angka kemiskinan (BPS, 2010).

Sesuai dengan perkembangan zaman masyarakat beranggapan bahwa pendidikan sangat penting. Pernyataan ini sesuai dengan penjelasan UU No. 2 Tahun 1989 tentang sistem pendidikan nasional dinyatakan bahwa "dalam kehidupan suatu bangsa, pendidikan mempunyai peranan yang amat penting untuk menjamin perkembangan dan kelangsungan kehidupan bangsa yang bersangkutan" (Tirtahardja, 2005). Di nagari Talu, masyarakat beranggapan bahwa pendidikan bisa merubah kehidupan mereka. Hal tersebut dapat dilihat dari data KK yang melanjutkan pendidikan seperti table di bawah ini :

Tabel 1

Data Keluarga Miskin Menyekolahkan Anaknya Ke Perguruan Tinggi di Nagari Talu

\begin{tabular}{|l|r|r|r|}
\hline \multicolumn{1}{|c|}{ Nama Jorong } & \multicolumn{1}{|c|}{$\begin{array}{c}\text { Jumlah } \\
\text { KK }\end{array}$} & $\begin{array}{c}\text { Jumlah } \\
\text { KK } \\
\text { Miskin }\end{array}$ & $\begin{array}{c}\text { Keluarga } \\
\text { Miskin yang } \\
\text { Melanjutkan } \\
\text { Studi }\end{array}$ \\
\hline Jorong Merdeka & 332 & 82 & 21 \\
\hline Jorong Patamuan & 329 & 105 & 10 \\
\hline Jorong Tobek Sirah & 652 & 227 & 26 \\
\hline Jorong perhimpunan & 153 & 52 & 45 \\
\hline Jorong sungai Joniah & 735 & 256 & $\mathbf{1 0 6}$ \\
\hline Jumlah & $\mathbf{2 . 2 0 1}$ & $\mathbf{7 2 2}$ & \\
\hline
\end{tabular}

Sumber : Data Nagari Talu Tahun 2013 
Dari data di atas terlihat bahwa dari 2.201 KK yang ada di Nagari Talu, 722 adalah KK miskin dan 106 KK dari KK miskin melanjutkan studi anaknya ke pergruan tinggi, baik perguruan tinggi Negri maupun Swasta. Dimana 15\% KK ini bermata pencaharian sebagai petani dan buruh. Petani adalah pemilik lahan dengan kepemilikan lahan $\pm 1 / 4$ Ha dan hasil panennya satu kali dalam satu tahun dan petani penggarap. Sedangkan buruh di sini yaitu orang yang pekerjaannya sebagai kuli bagunan. Sehingga untuk memenuhi kebutuhan hidupnya mereka masih susah. Malah ada juga yang tidak mencukupi., hal ini disebabkan oleh jumlah pengangguran mereka banyak, serta penghasilan yang tidak tetap. Tetapi mereka tetap melanjutkan studi anakanya ke perguruan tinggi. Tulisan ini akan menjelaskan motivasi orang tua miskin melanjutkan pendidikan anak mereka ke perguruan tinggi dan strategi yang mereka gunakan dalam melanjutkan pendidikan ankanya tersebut

\section{LITERATURE REVIEW}

Secara akademis, banyak studi tentang motivasi dan strategi melanjutkan studi yang sudah dilakukan sebelumnya. Penelitian yang dilakukan oleh Tisnawati Tapondhadhai yang berjudul Motivasi Masyarakat Petani Kelapa Terhadap Pendidikan Anak di Kecamatan Siberut Barat Kabupaten Kepulauan Mentawai misalnya. Hasil penelitiannya menyebutkan bahwa persepsi masyarakat petani kelapa di kecamatan Siberut Barat tergolong sangat baik, sehingga perlu dipertahankan dalam rangka mendukung keberhasilan anak menyelesaikan studi. Motivasi melanjutkan studi menurutnya adalah arus dan kemauan anak sekolah, lingkungan tepat tinggal dan pergaulan yang mendukung belajar dan terpenuhi kebutuhan selama sekolah (Tapondhadhai, Ansofino, \& Nazmi, 2012).

Penelitian lainnya dilakukan Wijayanti Mustika Sari tentang Strategi Rumah Tangga Penjaga Sekolah Honorer Di Kota Padang dalam Menunjang Pendidikan Anak. Penelitiannya menyimpulkan bahwa untuk menunjang pendidikan anak, rumah tangga selalu melakukan berbagai strategi. Strategi tersebut adalah dengan memotivasi dan pengawasan orang tua terhadap anak untuk giat belajar dan bersekolah, mengoptimalkan tenaga keluarga di rumah tangga dan tidak hanya mengandalkan penghasilan kepala keluarga, mengatur pengeluaran terhadap konsumsi rumah tangga serta meminjam kepada orang-orng terdekat untuk memeuhi kebutuhan biaya pendidikan anaknya (Sari, 2010). Kemudian Verawati tentang Partisipasi orang tua terhadap pendidikan Anak menyimpulkan bahwa partisipasi orang tua terhadap pendidikan anak pada Komunitas Tukang Ojek Di Kampus UNP Air Twar Barat adalah. aspirasi terhadap anak orang tua terhadap pendidikan anak, terlihat orang tua memiliki aspirasi yang tinggi terhadap pendidikan anaknya, orang tua tidak membatasi pilihan anak dalam menentukan sekolah yang diinginkan, termasuk harus memilih sekolah kejuruan. Orang tua beranggapan bahwa pendidikan adalah modal masa depan anak. Rata-rata orang tua tidak mengharapkan ankanya mengikuti jejak seagai tukangojek dan tukang ojek beranganggapan tidak selamanya menjadi tukang ojek. Partisipasi tukang ojek terhadap pendidikan anaknya termasuk tinggi, terlihat dalam kemampuan orang tua memberikan dana untuk biaya pendidikan anaknya. Dan terlihat dari kmampuan orang tua memperhatikan anaknya ketika belajar (Verawati, 2012).

Secara keseluruhan, terdapat kesamaan dan perbedaan antara penelitian ini dan penelitian terdahulu. Persamaan terdapat padda isu utama penelitian, yaitu tentang pendidikan dan upaya keluarga melanjutkan pendidikan anak-anak mereka. Namun demikian, penelitian-penelitian terdahulu belum membahas tentang motivasi dan strategi secara bersamaan dan juga tidak meneliti pendidikan pada perguruan tinggi. Penelitian ini lebih memfokukan terhadap bagaimana strategi keluarga miskin dalam melanjutkan studi anaknya ke perguruan tinggi di nagari Talu, Kecematan Talamau Kabupaten Pasaman Barat.

\section{METODE}

Penelitian ini menggunakan pendekatan kualitatif dengan tipe deskriptif. Infroman penelitian terdiri dari keluarga miskin yang melanjutkan studi anaknya ke Perguruan Tinggi. Data penelitian terdiri dari data primer dan data sekunder. Pengumpulan data dilakukan dengan cara observasi, wawancara mendalam dan studi 
dokumen dalam kurun waktu SeptemberOktober tahun 2013. Unit analisis penelitian adalah individu, yaitu orang tua miskin yang melanjutkan studi anaknya ke perguruan tinggi. Penelitian dilakukan di nagari Talu Kec. Talamau Kab. Pasaman Barat yang merupakan nagari dengan jumlah keluarga miskin terbanyak di Talamau yang melanjutkan studi anak mereka ke pergutuan tinggi.

\section{MOTIVASI MELANJUTKAN PENDIDIKAN ANAK KE PERGURUAN TINGGI}

\section{Merubah Hidup}

Pendidikan dianggap sebagai aset untuk masa yang akan datang. Berbagai cara yang dilakukan untuk mencapai pendidikan tinggi tersebut, dilihat di kalangan menengah ke bawah berbagai cara yang dilakukan untuk menyekolahkan anaknya ke perguruan tinggi. Motivasi slalu berkaitan dengan soal kebutuhan. Ada beberapa kebutuhan misalnya kebutuhan untuk menyenangkan orang lain, kebutuhan untuk mencapai hasil dan kebutuhan untuk mengatasi kesulitan. Maksud merubah nasib disini yaitu dimana orang tua berkeinginan untuk merubah nasibnya dengan melalui pendidikan yang tinggi terhadap anakanya. Berdasarkan dari pengamatan atau observasi yang penelii lakukan di kanagarian Talu, kec. Tamalau kab, Pasaman Barat. Suatu kesulitan atau hambatan mungkin menimbulkan rasa rendah diri, tapi hal ini menjadi dorongan untuk mencari kompensasi dengan usaha yang tekun dan luar biasa, sehingga tercapai kelebuhan atau keunggulan dalam bidang tertentu.

Berdasarkan teori Weber, tindakan rasional instumental seorang individu bertindak dan tepat untuk mencapai tujuan lain yaitu tujuan untuk merubah nasib. Tingginya keinginan orang tua untuk melanjutkan sekolah anaknya ke jenjang yang lebih tinggi karena orang tua beranggapan bahwa dengan pendidikan bisa merubah nasib keluarga. Hal ini dapat dfahami dari hasil wawancara dengan orang tua :

...."Supayo moso dopan anak lobiah baiak dari urang gaeknyo. Tu untuak maso dopan anak.
Pengetahuan e batambah, itu untuang-untuang lobiah sukses dari anak e.." (supaya masa depan anak jauh lebih abaikk dari orang tuanya. Pendidikan saat ini untuk masa depan anak dengan adanya pendidikan supaya bertambah pengetahuannya, mudahmudahan saja lebih sukses dari ibunya) (Wawancara YL, September 2013). ..."dongan malanjuik-an sakolah untuak dapeak maubah nasib ko, jan sampai kayak nasib amakn lo yang dirasoan samo anak" (dengan melanjutkan sekolah mudahmudahan bisa merubah nasib, jangan sampai nasib orang tuanya juga dirasakan oleh anak untuk yang akan datang) (wawancara YT, September 2013)

Ungkapan yang dsampaikan orang tua dalam wawancara di atas menunjukkan bahwa bagi mereka pendidikan merupakan aset untuk masa depan anak, dan pendidikan merupakan masa depan yang cerah dengan melanjutkan pendidikan dan dapat membawa perubahan yang lebih baik. Begitu pula harapan orang tua terhadap anaknya. Dengan menyekolahkan anaknya ke perguruan tinggi, orang tua berharap nasib anaknya menjadi lebih baik. Meskipun biiayanya mahal, akan tetapi motivasi orang tuanya tinggi. Orang tua tidak menginginkan anaknya bernasib sama dengannya. Oleh sebab itu orang tua ingin melanjutkan pendidikan ankanya ke perguruan tinngi meskipun dengan susah payah.

\section{Pengaruh Lingkungan}

Secara umum, Masyarakat nagari Talu meletakkan harapan dan arti yang tinggi terhadap pendidikan, khususnya pedidikan tinggi. Masyarakat berpendapat bahwa, dengan nilai-nilai tertentu yang disandang pendidikan tinggi, maka individu dapat di tempatkan pada satu strata atau lapisan tertentu. Nilai ini pada akhirnya melahirkan suatu keyakinan bahwa melalui pendidikan tinggi, seorang individu dapat memperoleh mobilitas sosial. 
Lingkungan yang menempatkan pendidikan pada pada posisi yang tinggi dan pentin membuat keluarga miskin ikut termotivasi untuk mlanjutkan pendidikan anak mereka ke perguruan tinggi. Sehingga keinginan dari orang tua untuk melanjutkan pendidikan anaknya ke perguruan tinggi disebabkan karena termotivasi oleh lingkungan sekitar.

Di lingkungan sekitar tempat tinggalnya banyak anak yang melanjutkan pendidikan ke perguruan tinggi dan mendapat pekerjaan yang membawa perubahan bagi kehidupan, seperti bekerja di rumah sakit dan perkantoran di Nagari Talu maupun diluar nagari Talu. Hal ini juga menyebabkan keluarga miskin berkeinginan anaknya sama suksesnya dengan anak di lingkungan sekitarnya. Wawancara infroman berikut menunjukkan bahwa mereka melanjtukan pendidikan karena lingkungan sekitar.

...."mancoliek anak urang yang alah berhasil malanjuik-an sakolahnyo, nio lo awak mancaliek anak awak berhasil pulo.. (melihat anak orang lain yang telah berhasil melanjutkan sekolahnya, saya juga ingin melihat anak saya ikut berhasil... (Wawancara YS, September 2013)

Kutipan wawancara di atas dapat menunjukkan bahwa motivasi terbesar orang tua untuk menyekolahkan anaknya adalah untuk memperoleh kehidupan yang lebih baik atau mapan sebagaimana juga dialami oleh orang lain di sekitar mereka. Disamping itu, mereka juga termotivasi karena di lingkungan setempatnya tidak banyak anak yang tidak melanjutkan pendidikan. Dengan demikian, mereka ikut terbawa arus lingkungan dimana tingkat pendidikan di lingkungan sangat baik.

\section{STRATEGI MELANJUTKAN PENDIDIKAN ANAK KE PERGURUAN TINGGI}

\section{Pola Nafkah Ganda}

Pola nafkah ganda menjadi salah satu strategi yang digunakan orang tua keluarga miskin dalam melanjutkan pendidikan anak ke perguruan tinggi. Sejumlah anggota rumah tangga usia kerja terlibat mencari nafkah di berbagai sumber, baik di sektor pertanian maupun luar pertanian. Dalam kegiatan usaha sendiri maupun sebagai buruh. Bagi rumah tangga miskin, arti dari pola nafkah ganda adalah strategi bertahan hidup, dimana sektor luar pertanian merupakan sumber nafkah penting untuk menutup kekurangan dari sektor pertanian. Dalam strategi nafkah ganda itu, wanita seperti juga pria, memiliki peran yang sangat penting sebagai pencari nafkah di dalam dan di luar pertanian. Wanita tidak hanya terlibat dalam kegiatan produksi yang tidak langsung menghasilkan pendapatan, tetapi juga dalam kegiatan produksi yang langsung menghasilkan pendapatan. Dengan demikian pola nafkah ganda disini yaitu tidak menghandalkan satu pekerjaan saja dan dimana perempuan terlibat dalam pemenuhan kebutuhan hidup tidak hanya laki-laki. Tidak ada bedanya antara laki-laki dan perempuan dalam pemenuhan hidup.

“....etek bakarajo mangaleh
kociak-kociak. Nyo manggaleh
lado samo kacang pera, dianta-
antaan ka kodai kodai urang,
kadang-kadang ka sekolah-sekolah
gai..." (ibu bekerja sebagai
pedagang kecil-kecilan. Dagang
keripik, kacang tujin jagung.
Dititipkan ke warung-warung dan
terkadang dititipkan ke kantin
sekolah) (wawancara YL,
September 2013)

Pada umumnya masyarakat Talu bermata pencarian petani, dan hasil panen hanya satu kali dalam setahun, itu pun belum bisa mencukupi kebutuhan sehari. Selain tani terkadang masyarakat menggunakan lahan sawah sebagai menanam palawija seperti : cabe, jagung, dan sayur. Masyarakat setempat memiliki pekerjaan sampingan seperti tukang. Tukang disini senbagai tukang biasa (buruh bangunan), pekerjaan tukang biasanyanya dilakukan di talu, kalau tidak ada pekerjaan di talu masyarakat tersebut bekerja ke tempat 
orang lain, atau ke sempang empat untuk mencari pekerjaan ke daerah lainnya. Sedangkan pekerjaan yang dilakukan oleh ibu untuk menolong agar penghasilan keluarga bertambah dengan cara membuat usaha kecil-kecilan di rumah dengan cara menitipkan ke warung-warung terdekat seperti keripik, mkanan dan usaha yang memiliki keahlian seperti tukang pijit dengan pendapatan \pm Rp.50.000 per hari, pendapatan tersebut tidak menetap.

\section{“....Apak bakarajo basawah, salain basawah apak bakarajo agen oto, sedangkan etek bakarajo manggaleh kociak-kociak dirumah. Mambuek galeh dilotakan kakodai- kodai urang, alhamdulillah lai bisa manambah pitih blanjo...". (Bapak bekerja sebagai petani, selain itu bapak juga bekerja sebagai agen angkutan umum. Ibu sendiri berdagang kecil-kecilan di rumah. Membuat dagangan yang dititipkan di warung orang lain) (Wawancara GS, September 2013).}

Dari penjelasan di atas dapat dilihat bahwa pola nafkah ganda yang dilakukan oleh orang tua untuk memenuhi kebutuhan hidup dan pendidikan, tidak hanya mengandalkan satu pekerjaan tapi mencari pekerjaan yang lain untuk menambah pendapatan keluarga. Dikarenakan kurangnya biaya untuk memenuhi kebutuhan pendidikan dan kebutuhan yang lainnya.

Menurut teori Tindakan Rasional Instrumental Max Weber orang tua telah berpikir rasional bahwa tindakan yang dipilihkan merupakan cara yang tepat untuk mencapai tujuan yaitu untuk melanjutkan studi anaknya ke perguruan Tinggi.

\section{Bantuan dari Keluarga Luas}

Strategi lain yang digunakan orang tua keluarga miskin dalam melanjutkan pendidikan anak ke perguruan tinggi adalah dengan memanfaatkan bantuan keluarga luas, yaitu bantuan berupa materi maupun non-materi. Bantuan diberikan langsung kepada anak yang melanjutkan pendidikan. Keluarga mendapat bantuan dari keluarga terdekat. Bantuan bisa dalam bentuk pemberian maupun pinjaman. Baik pemberian maupun pinjaman, keluarga tetap merasa terbantu oleh keluarga luas. Sehingga anak yang sedang bersekolah bisa melanjutkan sekolahnya dengan lancar. Jika bersifat pinjaman, pengembalian dilakukan dalam jangka waktu yang tidak terlalu lama. Waku yang diberikan biasanya paling lama satu bulan, namun pengembalian juga sering telat dilakukan.

"bantuan dari dunsanak lai untuak minjam lai yo, kalai maagihan kami samo manyakolahan anak lo jadi basolang.." (bantuan dari keluarga ada untuk minjam, kalau memberi kami sama-sama menyekolahkan anak jadi, hanya untuk pinjaman saja. (wawancara YL, September 2013)

Bantuan yang diberikan oleh keluarga luas tidak secara berkala, namun lebih sering adalah dalam bentuk incidental. Karena betapapun, kelaurga juga membutuhkan biaya untuk kehidupan mereka. Besaran bantuan juga tidak selalu sama, tergantung pada kondisi keuangan mereka.

"lai bantuan dari dunsanak tapi bantuan tu dak monantu kalau lai $e$ baraasoki diaagiah $e$, untuk tambah bayia uang sakolah" (ada bantuan dari keluarga tapi tidak terlalu sering, bantuan dari keluarga tergantung keadaan ekonominya). (wawancara SF, September 2013).

\section{Meminjam}

Strategi terakhir yang digunakan oleh orang tua kelaurga miskin dalam mealnjutkan pendidikan anak ke Perguruan Tinggi adalah dengan miminjam. Meminjam dilakukan sebagai benteng akhir jika tidak ada jalan keluar sama sekali dalam memenuhi kebutuhan pendidikan anak. Biasanya, mereka meminjam kepada keluarga dan atau kepada tetangga. Bisanya mereka 
meminjam tidak dalam jangka waktu yang lama dan hanya untuk kebutuhan pendidikan saat itu saja. Untuk pengembalian mereka lakukan dengan cara menyisihkan sebagian uang belanja perminggu.

\begin{abstract}
"kok kakurangan pitih etek untuak manambah pitih kuliah biasonyo etek manyolang $k a$ tetangga. Manyolang $e$ dak lamo-lamo wakatu nyo doh". (untuk mengatasi kekurang biaya kuliah, saya biasanya meminjam ke tetangga, namun tidak dalam tenggat waktu yang lama. (wawancara YE, September 2013).
\end{abstract}

\section{Beasiswa}

Beasiswa merupakan tunjangan uang yang diberikan kepada pelajar atau mahasiswa sebagai bantuan belajar (Moeliono, 1993). Beasiswa dapat diberikan oleh lembaga pemerintah, perusahaan ataupun yayasan. Pemberian beasiswa dapat dikategorikan pada pemberian cuma-Cuma atau pemberian degan ikatan kerja (biasa disebut ikatan dinas) setelah selesainya pendidikan. Jenis beasiswa ini adalah untuk mendanai kegiatan akademik para maghasiswa yang kurang beruntung, tetapi memiliki prestasi. Komite beasiswa biasanya memberikan beberapa penilaiaan pada kesulitan ini, misalnya pendapatan orang tua, jumlah saudara kandung yang sama-sanma tengah menempuh studi, pengeluaran, biaya hidup, dan lain-lain.

Orang tua keluarga miskin di Talu menjadikan beasiswa sebagai salah satu strategi melanjtukan pendidikan anaknya. Mereka mengupayakan persyaratan-persyaratan yang dibutuhkan anak mereka untuk mendapatkan beasiswa seperti surat keterangan kurang mampu (SKTM) dari kelurahan, tanda terima Raskin dan berkas-berkas lainnya yang dibutuhkan sehingga anak mereka memenuhi syarat untuk mendapatkan beasiswa. Beasiswa yang mereka upayakan terutama adalah beasiswa bantuan dari pemerintah untuk biaya pendidikan berprestasi untuk anak yang kurang mampu.

\section{PENUTUP}

Motivasi utama orang tua keluarga miskin nagari Talu, Kecematan Talamau Kabupaten Pasaman Barat dalam melanjutkan pendidikan anak mereka ke perguruan tinggi adalah merubah nasib. Faktor lingkungan adalah faktor tambahan yang membuat mereka juga termotovasi. Motivasi tersebut muncul karena melihat kesuksesan orang lain di sekitar mereka karena pendidikan yang baik. Untuk melanjutkan pendidikan tersebut mereka menggunakan berbagai strategi. Strategi utama nya adalah pola nafkah Ganda, bantuan dari keluarga luas, meminjam dan mendapatkan beasiswa.

\section{DAFTAR PUSTAKA}

Amtu, O. (2011). Manajemen Pendidikan Di Era Otonomi Daerah. bandung: alfabeta.

BPS. (2010). Data Dan Informasi Kemiskinan. Jakarta: CV. Rioma.

Maliki, Z. (2010). Sosiologi Pendidikan. Yogyakarta: Gajah MadaUniversity Press.

Moeliono, A. (1993). Kamus Besar Bahasa Indonesia. Jakarta: Balai Pustaka.

Sari, M. W. (2010). Strategi Rumah Tangga Penjaga Sekolah Honorer Di Kota Padang Dalam Menunjang Pendidikan Anak. Sekolah Tinggi Keguruan dan Ilmu Pendidikan (STKIP) PGRI Sumatera Barat, Padang.

Setiadi, E., \& Kolip, U. (2011). Pengantar Sosiologi Pemahaman Dan Gejala Permasalahan Sosial. jakarta: Kencana.

Suharto, E. (2009). Kemiskinan Dan Perlindungan Sosial Di Indonesia Menggagas Model Jaminan Sosial Universal Bidang Kesehatan. Bandung: Alfabeta.

Tapondhadhai, A. T., Ansofino, \& Nazmi, R. (2012). Persepsi Masyarakat Petani Kelapa Terhadap Pendidikan Tinggi Anak di Kecamatan Siberut Barat, Kabupaten Kepulauan Mentawai. Jurnal Ilmu Sosial Mamangan, 1(2), 102-108.

Tirtahardja, U. (2005). Pengantar Pendidikan. jakarta: PT Rineka Cipta.

Verawati. (2012). Partisipasi Orang Tua Terhadap Pendidikan Anak (Kasus Pada Komunitas Tukang Ojek Di Kampus UNP 
Air Tawar Barat). Universitas Negeri

Padang, Padang.

Jurnal Ilmu Sosial Mamangan, Volume II Nomor 2, juli-Desempber 2013 | 81 
